\title{
Evaluation of Antioxidant, Analgesic and Cytotoxic Activities of Typha angustata L. Root
}

\author{
Fahrima Islam, Amir Hossain, Md. Golam Hossain, Gazi Md. Monjur Murshid and \\ Md. Mustafizur Rahman
}

\author{
Pharmacy Discipline, Life Science School, Khulna University, Khulna-9208
}

\begin{abstract}
Received: November 09, 2014; Accepted: April 30, 2015; Published (web): June 15, 2015
ABSTRACT: Ethanolic extract of the root of Typha angustata was evaluated for antioxidant, analgesic and cytotoxic activities. T. angustata extract exhibited DPPH free radical scavenging activity with IC $_{50}$ value of 124.96 $\pm 0.93 \mu \mathrm{g} / \mathrm{ml}$. The total phenolic and tannin content were found to be $596.73 \pm 1 \mathrm{mg} \mathrm{GAE} / 100 \mathrm{~g}$ and $319.68 \pm 64$ mg GAE/100 g of dried plant material, respectively. Analgesic activity was determined using acetic acid induced writhing inhibition in mice model. The root extract, at doses of $250 \mathrm{mg} / \mathrm{kg}$ and $500 \mathrm{mg} / \mathrm{kg}$ body weight, showed inhibition of writhing reflex by 33.55\% $(\mathrm{p}<0.01)$ and $56.78 \%(\mathrm{p}<0.001)$, respectively. Cytotoxicity of the extract was measured by brine shrimp lethality bioassay where the $\mathrm{LC}_{50}$ against brine shrimp nauplii was found to be $41.54 \mu \mathrm{g} / \mathrm{ml}$.
\end{abstract}

Key words: Typha angustata, antioxidant, analgesic, cytotoxic

\section{INTRODUCTION}

Typha angustata, locally known as 'Kaaba", is called Lesser Indian Reed mace from Typhaceae family. It is a perennial plant found throughout India and has been reported in many Indian, Chinese and Turkey literatures. ${ }^{2,3}$ The plant is used for treatment of wounds, boils, ulcers, bleeding piles, ${ }^{2-4}$ calculi, dysuria, leprosy, inflammation, ${ }^{4-6}$ eczema $^{7}$ and as astringent and antiseptic. ${ }^{8}$

Free radicals are responsible for destruction of protein, as well as lipid and DNA by oxidative process during aerobic metabolism in the biological system ${ }^{9}$ leading to many degenerative and chronic diseases including carcinogenesis, atherosclerosis, ischemic cardiac disease, diabetes mellitus, immunocompromised and neurodegenerative diseases etc. ${ }^{10}$ Antioxidants protect human body against free radicals by scavenging them. ${ }^{11}$ Brine shrimp lethality bioassay is considered as useful tool for preliminary assessment of toxicity and it has been

Correspondence to: Md. Mustafizur Rahman

E-mail: dipti0103@yahoo.com

Telephone: +880 1711485602 used for the detection of fungal toxins, plant extract toxicity, heavy metals' toxicity, cyanobacteria toxins, pesticides etc. ${ }^{12}$

Analgesic agents retard or eliminate algesia or pain by acting on the sensory nervous system without significantly altering consciousness. Synthetic drugs (NSAIDs) cause multiple unwanted effects including gastrointestinal discomfort, ulcers, bleeding etc. There are very few reports that describe the scientific justification supporting the traditional use of $T$. angustata root. That is why the present study was undertaken in the investigation of the antioxidant, analgesic and cytotoxic activities of the root extract of T. angustata plant using in-vitro and in-vivo models.

\section{MATERIALS AND METHODS}

Plant material. T. angustata (Typhaceae) roots were collected from Barisal, Bangladesh on November, 2012 and was identified by the experts of Bangladesh National Herbarium, Mirpur, Dhaka (voucher specimen no. DACB 38719). 
Extract preparation. The plant roots were properly washed with fresh water to eliminate filthy materials and were shade dried for 3 weeks to obtain consistent weight. About $300 \mathrm{~g}$ of powered material was soaked in ethanol and $4.81 \mathrm{~g}$ crude extract was obtained from it and \% of yield found was $1.6 \% \mathrm{w} / \mathrm{w}$ of dried plant material.

Chemicals. 1, 1-diphenyl-2-picrylhydrazyl (DPPH), gallic acid (GA), ascorbic acid (AA), DMSO, diclofenac sodium, tween-80 was purchased from Sigma Chemical Co. (St. Louis, MO, USA); Folin-Ciocalteu's phenol reagent and sodium carbonate were obtained from Merck (Damstadt, Germany).

Phytochemical screening. Standard qualitative procedures were followed to identify the chemical constituents of $T$. angustata using standard protocols. $^{13}$

DPPH free radical scavenging assay. Antioxidant activity was determined following DPPH free radical scavenging activity of the extract using the method of Liyana-Pathiranan \& Shahidi. ${ }^{14}$ Ascorbic acid was used as reference. The DPPH scavenging ability was calculated by the following equation:

DPPH radical scavenging activity (\%) = $\left.\left[\left(\mathrm{Abs}_{\text {control }}-\mathrm{Abs}_{\text {sample }}\right)\right] /\left(\mathrm{Abs}_{\text {control }}\right)\right] \times 100$

Where, $\mathrm{Abs}_{\text {control }}$ is the absorbance of DPPH radical + methanol; $\mathrm{Abs}_{\text {sample }}$ is the absorbance of DPPH radical + sample extract/standard.

Determination of total phenolics. Determination of total phenolics was performed by the modified Folin-Ciocalteu method. ${ }^{15}$ Gallic acid solution (20-100mg/l) was used for standard calibration curve and total phenolic content was expressed as gallic acid equivalent per gram of dried plant extract.

Determination of total tannins. Determination of total tannin content of the extract was done by Folin-Ciocalteu reagent that is described by Marinova et al. ${ }^{15}$ Gallic acid (15.7-500mg/l) was used for standard calibration curve and total tannin content was expressed as mg/g gallic acid equivalent.
Acetic acid-induced writhing method. Analgesic activity was evaluated using acetic acid induced writhing method in mice, with slight modification. ${ }^{16}$ In this method, intra-peritoneal administration of acetic acid was performed on the experimental animals to create pain sensation. Diclofenac sodium was used in the present study as positive control. Oral administration of the plant extract was performed in two different doses (100 and $200 \mathrm{mg} / \mathrm{kg}$ body weight) to the Swiss Albino mice after an overnight fasting. Test samples and vehicle were administered orally 30 minutes prior to intraperitoneal administration of $0.7 \% \mathrm{v} / \mathrm{v}$ acetic acid solution $(0.1 \mathrm{ml} / 10 \mathrm{~g})$ but diclofenac sodium was administered 15 minutes before acetic acid injection. Then the animals were put on an observation table. Each mouse of all groups were observed separately for counting the number of writhing they made in 15 minutes commencing just 5 minutes after the intraperitoneal administration of acetic acid solution. The number of writhes in each treated group was compared to that of a control group.

Brine shrimp lethality bioassay. Brine-shrimp lethality bioassay was followed to assess cytotoxic activity of $T$. angustata which is described by McLaughlin et al. ${ }^{17,18}$ Vincristine sulphate was used as positive control at the concentrations of 5, 2.5, 1.25, 0.625 and $0.325 \mu \mathrm{g} / \mathrm{ml}$. After an incubation period of $24 \mathrm{~h}$ at room temperature, the number of viable naupliis was counted using a magnifying glass. The $\mathrm{LC}_{50}$ values were determined with the help of Probit Analysis Chart using computer software "LdP line software".

Statistical analysis. All analyses were carried out in two replications. \pm SEM was used to present data. For each experimental parameter estimation, the significance level was determined using correlation and regression analysis and the t-tests $(\mathrm{p}<0.001)$. A free R-software version: 2.15.1 (http://www.rproject.org/) and Microsoft Excel 2010 also aided statistical and graphical evaluations as well. 


\section{RESULTS AND DISCUSSION}

Phytochemical screening: Phytochemical screening of $T$. angustata showed the presence of reducing sugar, tannins, glycosides, saponins, flavonoid and steroid (Table 1). However alkaloids and gums were not detected. Pawar et al. ${ }^{19}$ worked with the methanolic extract of leaves of $T$. angustata and reported the presence of tannins, glycosides, saponins, flavonoid, steroid and alkaloid.

Anti-oxidant activity: Although $T$. angustata leaf extract possesses anti-oxidant activity, ${ }^{19}$ to the best of our knowledge, there is no report about the antioxidant activity of $T$. angustata root. Here, we found that the ethanolic root extract possesses antioxidant activity. DPPH free radical scavenging assay on ethanolic extract of $T$. angustata root showed $\mathrm{IC}_{50}$ (inhibitory conc. 50\%) value $124.96 \pm$ $0.93 \mu \mathrm{g} / \mathrm{ml}$. Whereas, standard ascorbic acid showed $\mathrm{IC}_{50}$ value of $6.67 \pm 0.08 \mu \mathrm{g} / \mathrm{ml}$ (Figure 1). Gallic acid calibration curve was used to determine total phenolic and total tannin content of $T$. angustata (Figure 2a and 2b). Total phenolic and total tannin content were $596.73 \pm 1 \mathrm{mg} \mathrm{GAE} / 100 \mathrm{~g}$ and $319.68 \pm$ $64 \mathrm{mg}$ GAE/100 g of dried plant material, respectively.

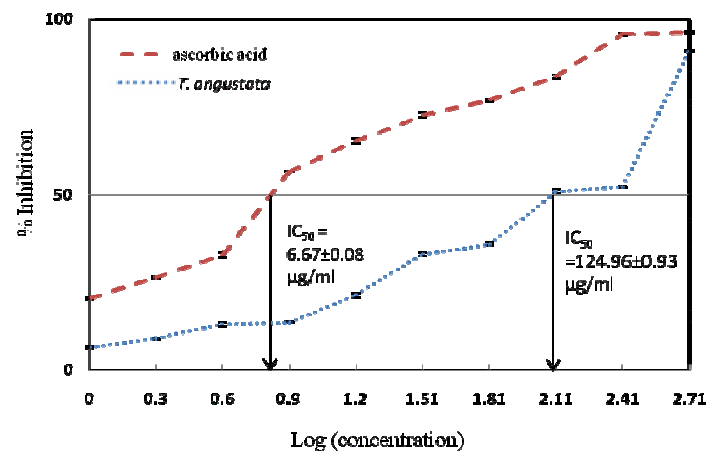

Figure 1 . DPPH scavenging activity of $T$. angustata and positive control (ascorbic acid)

Table 1. Result of phytochemical screening of $T$. angustata.

\begin{tabular}{ll}
\hline Phytochemical groups & Observed result \\
\hline Reducing sugar & + \\
Alkaloid & - \\
Tannins & + \\
Glycosides & + \\
Saponins & + \\
Flavonoid & + \\
Steroid & + \\
Gum & - \\
\hline +, presence; -, absence &
\end{tabular}

Table 2. Analgesic activity of $T$. angustata in acetic acid-induced pain model.

\begin{tabular}{|c|c|c|c|c|c|c|}
\hline Animal group & $\begin{array}{l}\text { Mean of } \\
\text { writhing }\end{array}$ & \%Writhing & SD & SE & $\begin{array}{l}\% \text { Inhibition of } \\
\text { writhing }\end{array}$ & $\begin{array}{l}\text { T-test } \\
\text { (value of } p \text { ) }\end{array}$ \\
\hline Negative control & 31 & 100 & 3.16 & 1.41 & 0 & - \\
\hline $\begin{array}{l}\text { Positive control (diclofenac-Na) } \\
\text { ( } 25 \mathrm{mg} / \mathrm{kg} \mathrm{bw})\end{array}$ & 7.4 & 23.87 & 1.95 & 0.87 & 76.13 & $14.24^{*}$ \\
\hline Extract (250 mg/kg bw) & 20.6 & 66.45 & 1.14 & 0.51 & 33.55 & $6.93 * *$ \\
\hline Extract $(500 \mathrm{mg} / \mathrm{kg})$ & 13.4 & 43.22 & 1.34 & 0.6 & 56.78 & $11.48 *$ \\
\hline
\end{tabular}

$* \mathrm{P}<0.001, * * \mathrm{P}<0.01, \mathrm{SD}=$ Standard deviation, $\mathrm{SE}=$ Standard error

Table 3. Result of brine shrimp lethality bioassay of root extract of $T$. angustata.

\begin{tabular}{ccccccc}
\hline $\begin{array}{c}\text { Conc. } \\
(\mu \mathrm{g} / \mathrm{ml})\end{array}$ & $\begin{array}{c}\text { Log } \\
\text { conc. }\end{array}$ & $\begin{array}{c}\text { No. of alive } \\
\text { shrimp in Test-1 }\end{array}$ & $\begin{array}{c}\text { No. of alive } \\
\text { shrimp in Test-2 }\end{array}$ & $\begin{array}{c}\text { Avg. no. of alive } \\
\text { shrimp } \\
\text { (Sample) }\end{array}$ & $\begin{array}{c}\text { Avg. no. of alive } \\
\text { shrimp } \\
\text { (Control) }\end{array}$ & \% Mortality \\
\hline 5 & 0.698 & 9 & 9 & 9 & & 3.23 \\
10 & 1 & 8 & 7 & 6.5 & 9.3 & 39.35 \\
20 & 1.301 & 7 & 6 & 4 & & 56.11 \\
40 & 1.602 & 5 & 4 & 4 & 56.99 \\
80 & 1.903 & 4 & 2 & 1.5 & & 83.89 \\
160 & 2.204 & 1 & 1 & 0.5 & & 94.62 \\
320 & 2.505 & 0 & &
\end{tabular}


Analgesic activity: In the present study the ethanolic extract of $T$. angustata root showed analgesic activity by presenting writhing inhibition $33.55 \%(\mathrm{p}<0.01)$ and $56.78 \%(\mathrm{p}<0.001)$ at 250 $\mathrm{mg} / \mathrm{kg}$ and $500 \mathrm{mg} / \mathrm{kg}$ doses, respectively. The extract showed analgesic activity in a dose dependent manner whereas, diclofenac-Na (25 $\mathrm{mg} / \mathrm{kg})$, the positive control, showed $76.13 \%$ writhing inhibition (Table 2). The obtained results are in agreement with the previous study done by Pawar et al. ${ }^{19}$ where methanolic extract of leaves of $T$. angustata was found to have analgesic activity.

a. Total Phenolic Content

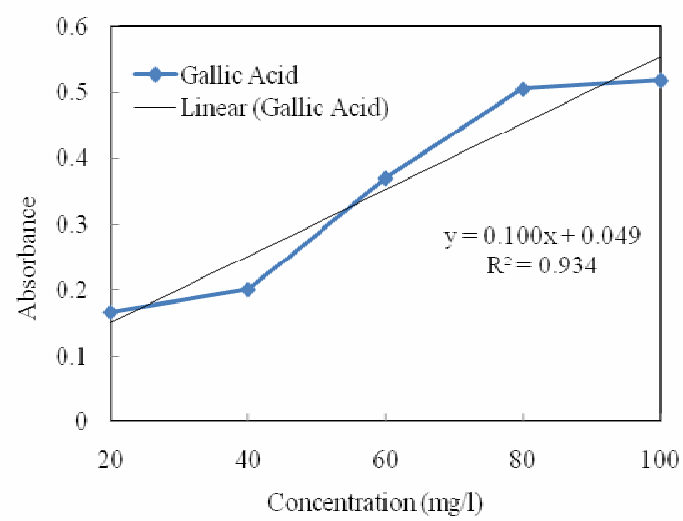

b. Total Tannin Content

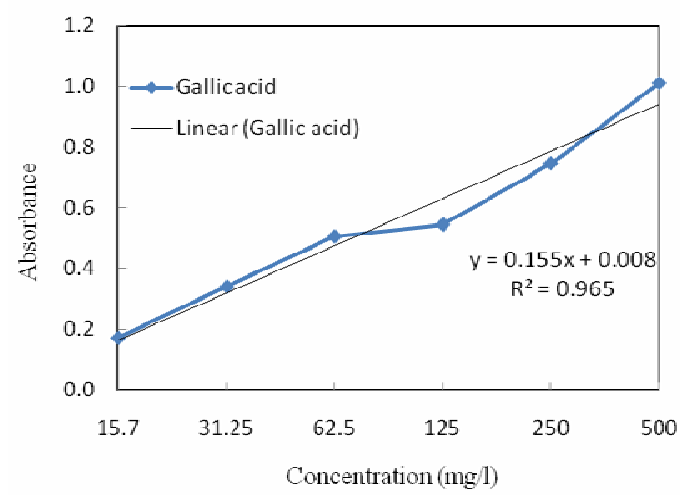

Figure 2. Determination of total phenolic (a) and tannin (b) contents of $T$. Angustata.

Cytotoxicity by brine shrimp lethality bioassay: The root extract of $T$. angustata and the positive control vincristine sulphate caused the nauplii death and the percentage mortality of the nauplii caused by them is presented in table 3. Probit analysis software (LdP Line software, USA) was used to determine $\mathrm{LD}_{50}$ for both sample and positive control and the $\mathrm{LD}_{50}$ was found to be $41.54 \mu \mathrm{g} / \mathrm{mL}$ for root extract whereas, vincristine sulfate showed $0.72 \mu \mathrm{g} / \mathrm{mL}$ (Figure 3).

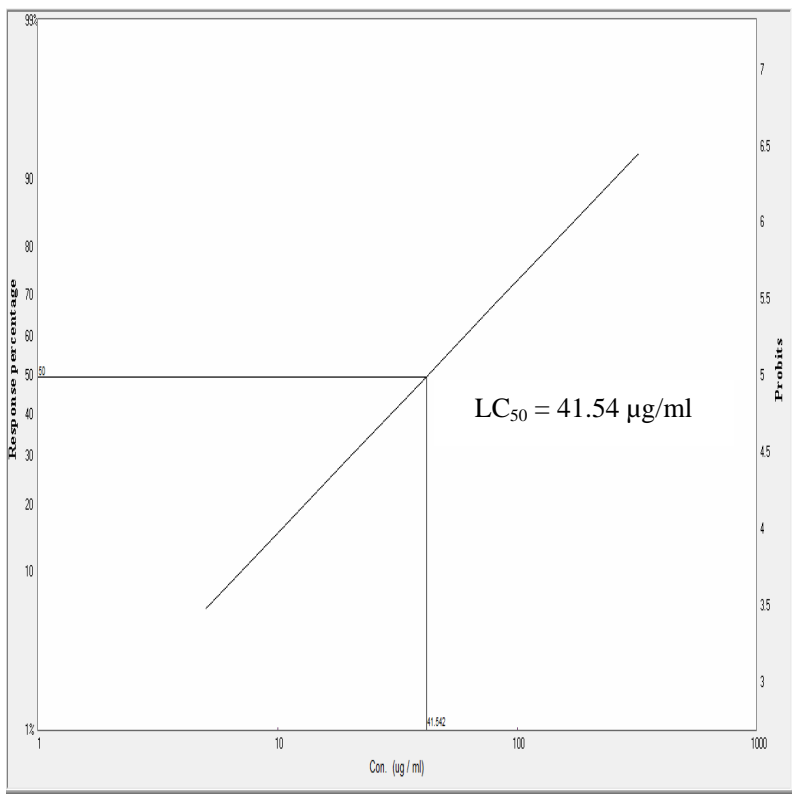

a. T. angustata

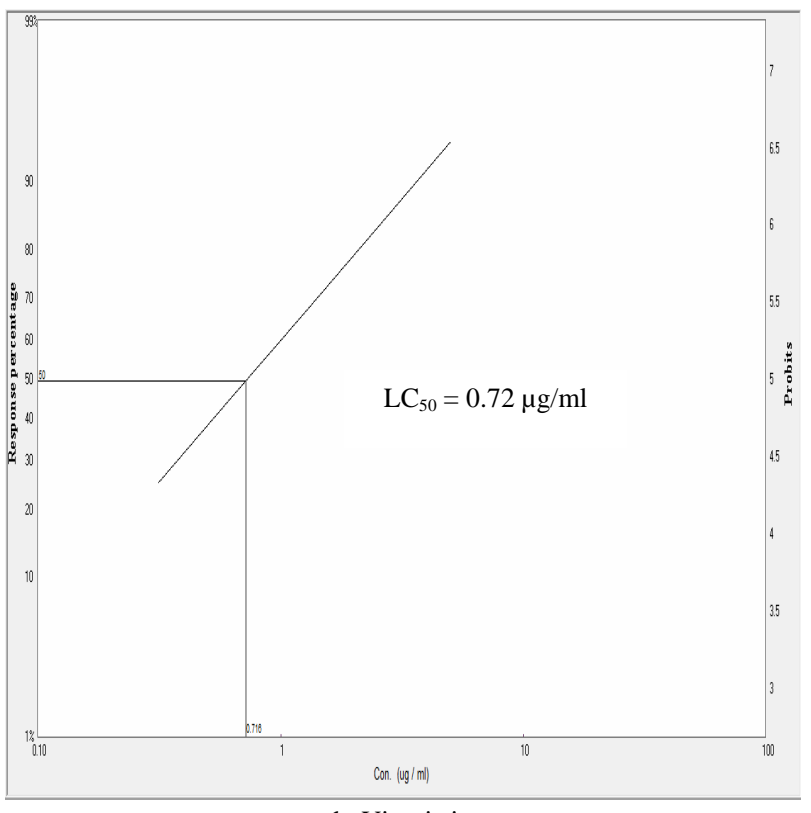

b. Vincristine

Figure 3: Graphical representation of brine shrimp lethality bioassay and $\mathrm{LC}_{50}$ for the ethanolic root extract of $T$. angustata (a) and vincristine (b) by Ldp line software. 
The results of our investigation demonstrated that ethanolic extract of $T$. angustata possesses antioxidant, analgesic and cytotoxic activities indicating the presence of pharmacologically active compounds in the crude root extract. These findings constitute the scientific basis of the traditional uses of the plant. Further studies are needed to confirm the activities, isolate the active compounds and explain the probable mechanisms related to these possible pharmacological effects.

\section{ACKNOWLEDGEMENT}

The authors are thankful to the authority of International Centre for Diarrhoeal Disease and Research, Bangladesh (ICDDR, B) for providing the experimental mice.

\section{REFERENCES}

1. Zhongcaoyao. 1983. Chemical constituent of Typha. Chem. Abstr. 14, 98-99.

2. Sezik, E., Yesilada, E., Tabata, M., Honda, G., Takaishi, Y. and Fujita, T. 1997. Traditional Medicine in Turkey VIII. Folk Medicine in East Anatolia; Erzurum, Erzincan, Adry, Kars, Iddyr Provinces. Econ. Bot. 51, 195-211.

3. Bailey, L.H. and Bailey, E.Z. 1976. National Institute of Science Communication. The Wealth of India. New Delhi. CSIR Publ. 10, 400.

4. Rastogi, R.P. and Mehrotra, B.N. 1983. Compendium of Indian Medicinal Plants. New Delhi: CSIR Publ. 3, 663.

5. Yesilada, E., Akkol E.K., Ipek, S. and Hikmet, K. 2011. The potential role of female flowers inflorescence of Typha domingensis Pers. in wound management. $J$. Ethnopharmacol. 133, 1027-1032.

6. Khan, A.K. and Khanum, A. 2009. Herbal Therapy for Skin Infection. 1st ed. Hydrabad. Ulkaaz Publication.

7. Sheth, A.K. 2005. The Herbs of Ayurveda. In: Sheath AK, editor, 1st ed. Gujarat: Hi Scan Pvt. Ltd. Distributors.
8. Duke, J.A. and Ayensu, E.S. 1985. Medicinal Plants of China. Vols 1 \& 2, Reference Publ., Inc. Algonac. Michigan, United States of America, p. 705

9. Kalaiselvi, M., Narmadha. R., Ragavendran, P., Ravikumar, G., Gomathi, D., Sophia, D., Arulraj, C., Uma, C. and Kalaivani, K. 2012. In vitro and In vivo antitumor activity of Jasminum sambac (Linn) Ait oleaceae flower against Dalton's ascites lymphoma induced Swiss albino mice. Int. J. Pharm. Pharm. Sci. 4, 144-147.

10. Stanner, A., Hughers, j., Kelly, C.N. and Buttriss, J. 2004. A review of the epidemiological evidence for the 'antioxidant hypothesis'. Public Health Nutr. 7, 407-422.

11. Oke, J.M. and Hamburger, M.O. 2002. Screening of some Nigerian medicinal plants for antioxidant activity using 2, 2, diphenyl-picryl-hydrazyl radical. A. J. Biomed. Res. 5, 77-79.

12. Michael, A.S., Thompson, C.G. and Abramovitz, M. 1956. Artemia salina as a test organism for a bioassay. Science. 123, 464.

13. Ghani, M.A. 2003. Medicinal Plants of Bangladesh. Asiatic Society of Bangladesh.

14. Liyana, P.C.M. and Shahidi, F. 2005. Antioxidant activity of commercial soft and hard wheat (Triticumaestivum L) as affected by gastric pH conditions. J. Agri. Food Chem. 53, 2433-2440.

15. Marinova, D., Ribarova, F. and Atanassova, M. 2005. Total phenolics and total flavonoids in Bulgarian fruits and vegetables. J. Univ. Chem. Technol. Metall. 40, 255-260.

16. Whittle, B.A. 1964. The use of changes in capillary permeability in mice to distinguish between narcotic and nonnarcotic analgesics, Br. J. Pharmacol. Chemother. 22, 246253.

17. McLauglin, J.L., Chang, C.J. and Smith, D.L. 1991. Bench top bioassay for the discovery of bioactive natural products: an update. In: Studies on National Products Chemistry (Rahman, A.U., ed.), Elsevier, Amsterdam, 9, pp. 383-409.

18. Gurkan, E., Tuzun, O.T. and Hirlak, F. 1995. Cytotoxic assay of some papaver alkaloids using Artemia saline (Brine shrimp). Fititerapia 66, 544-545.

19. Pawar, C.R., Kolhe, V.N. and Khedkar, P.A. 2011. Antiinflammatory activity of leaves of $T$. angustata (Typhaceae). Int. J. Res. Ayur. Pharm. 2, 1598. 